\title{
The Interactive Effect of Sewage Sludge Application with Phytohormones IAA or SA on Three Broad Bean Cultivars
}

\author{
Hamdia M. Abd El-Samad*, Sara H. Abd Nabi, Khloud N. S. Abd El-Hakeem \\ Botany and Microbiology Department, Faculty of Science, El-Minia University, Minya, Egypt \\ Email: ^hamdia10@yahoo.com
}

How to cite this paper: Abd El-Samad, H.M., Abd Nabi, S.H. and Abd El-Hakeem, K.N.S. (2020) The Interactive Effect of Sewage Sludge Application with Phytohormones IAA or SA on Three Broad Bean Cultivars. American Journal of Plant Sciences, 11, 880-895.

https://doi.org/10.4236/ajps.2020.116064

Received: May 11, 2020

Accepted: June 27, 2020

Published: June 30, 2020

Copyright $\odot 2020$ by author(s) and Scientific Research Publishing Inc. This work is licensed under the Creative Commons Attribution International License (CC BY 4.0).

http://creativecommons.org/licenses/by/4.0/ (c) (i) Open Access

\begin{abstract}
The present work has been performed to study the growth and metabolic activities of three broad bean cultivars (Giza 843, Sakha 1, and Giza 716) which are shown to have different response to sewage sludge applications and to determine the effects of phytohormones IAA or SA. Along with identifying the mechanisms of broad bean response and the role of growth regulators (200 ppm of IAA or $10 \mathrm{mM}$ of SA) in counteract sewage sludge effects is examined. The situation can be recorded that growth parameters fresh, dry matter and water content of pods were significantly increased as increasing SSL in cv. Giza 843 and in cv. Sakha 1 up to $70 \%$ level. However, these parameters were markedly decreased as increasing SSL in cv. Giza 716. Length and number of pods were unchanged in cv. Sakha 1, increased in cv. Giza 843 while, they were decreased in cv. Giza 716 with increasing SSL. Phytohormonal application stimulated growth parameters in pods of three tested cultivars Giza 843, Sakha 1 and Giza 716 with sewage sludge treatments. Soluble sugar and soluble protein contents were decreased as increasing SSL in both cv. Sakha 1 and cv. Giza 716. In cv. Giza 843, soluble sugar was significantly increased while soluble protein was decreased as increasing SSL. Proline content was unchanged in cv. Sakha 1, increased in cv. Giza 716 while, it was decreased in cv. Giza 843. Metabolites (soluble sugar, soluble protein and proline) showed variations in three broad bean cultivars to IAA or SA application plus sewage sludge treatments. In cv. Giza 716, SS treatment increased $\mathrm{Zn}, \mathrm{Ni}, \mathrm{PB}$ and $\mathrm{Cu}$. In cv. Giza 843, SS treatment decreased $\mathrm{Zn}, \mathrm{Pb}$, and $\mathrm{Cu}$ while increased Ni. In cv. Sakha 1 , SS treatment decreased $\mathrm{Zn}, \mathrm{Ni}, \mathrm{Pb}$ and $\mathrm{Cu}$. Phytohormonal treatments showed an increasing or decreasing effect in heavy metals in three tested cultivars.
\end{abstract}

\section{Keywords}

Sewage Sludge, IAA, SA, Broad Bean Cultivars 


\section{Introduction}

Agriculture actions in the El-Minia distinct of central Egypt hinge on water removal from the River Nile along secondary canals. Maximum of cultured land are watered by saturating methods that next generate an additional of subsoil water. A result of the constant rise in the water quantity, soil strength and salt concentrations are affected, which clues to problems of water logging. For these reasons, drilling of the El-Moheet drain is directed to decrease the water level, mainly on the western bank of the Nile Valley. This drain receives sewage, industrial, and agronomic unwanted waters from other negligible drains. The main danger is the straight linking between this drain and the River Nile through a subsidiary Etsa drain. However, contamination is probable for groundwater in the region around the drain as exposed by Abdel-Dayem, (2011) [1]. The region between nearby the drains was sensibly chosen for polluted soil [2] [3] [4].

Sewage sludge is waste organic wide and biogenic compounds especially nitrogen and phosphorus which are essential for plant growth [5] [6] [7]. Conversely it also contains heavy metals in addition to those classified as poisonous ( $\mathrm{Cd}, \mathrm{Cr}, \mathrm{Cu}, \mathrm{Hg}, \mathrm{Ni}, \mathrm{Pb}$ and $\mathrm{Z}$ ) [8] [9]. Provisional on the concentration and exposure time, an assumed metal can carriage environmental and fitness risks which are unified with its bulk to bioaccumulation the food chain [10]. The highest community origins of heavy metals in sewage sludge are national and manufacturing wastewaters and deterioration of sewage systems, as well as surface run from recognized areas or streets [11] [12]. Zeid and Abou El Ghate (2007) [13] showed that seed germination and growth of bean seedlings were fortified by irrigation with sewage water. Growth encouragement was attended with increase pigment production, carbohydrate, nucleic acids, and nitrogenous compounds, except amino acids $\mathrm{N}$ was reduced. Increased enzymes activity (amylase, invertase and protease) with sludge treatments may be due to the presence of specific ions which action as activator for these enzymes. Additioally, the effect of sewage sludge on nutrient uptake and growth parameters of larch seedlings (Larix decidua), minerals and heavy metals and scattering were studied by Bourioug (2014) [14]. The extreme foremost metals in sludge were $\mathrm{Zn}$ and $\mathrm{Cu}$. Sludge differences in hormone and stress prompting activities of municipal wastewater in straight activated sludge wastewater use plant water [15]. Correspondingly, Klimas et al. (2016) [16] stated that presentation of products as composts covering phytohormones in plants. Growth corrected of signals system improved nutrient uptake, improved stress and decease resistance and delayed aging. Bucker-Neto et al. (2017) [17] demonstrated the role of phytohormones, abscisic acid and brassinosteroid and ethylene in signaling pathways, defense mechanisms and alleviation of metal toxicity. Actually, Tytla et al. (2019) [18] worked on the contamination and potential ecological risk of seven heavy metals ( $\mathrm{Cd}, \mathrm{Cr}, \mathrm{Cu}, \mathrm{Ni}, \mathrm{Hg}, \mathrm{Pb}$ and $\mathrm{Zn}$ ) in the sewage sludge accumulating from a wastewater treatment positioned in the most industrialized area of Poland. 
Thus the present work was carried out to illustrate the effect of sewage sludge and interactive with phytohormones (IAA or SA) on growth, metabolites and heavy metals on three broad bean cultivars.

\section{Material and Methods}

\subsection{Experimental Sites and Sewage Sludge Treatments}

Broad bean plant is important economic crop plant and considers the first plant food for Egyptian people because it contains highly benefit protein and other essential elements for man healthy. In Egypt, faba beans is the most common fast food item in the Egyptian diet, eaten by rich and poor alike. Egyptians eat faba beans in various ways. The prepared beans, called fulmedames, are then eaten with bread. Faba bean is an excellent source of protein (20\% - 25\%), calcium $(0.15 \%)$, phosphorus $(0.50 \%)$, lysine $(1.5 \%)$ and methionine-cysteine $(0.5 \%)$ in dry weight. It is also an excellent source of complex carbohydrates, dietary fiber, choline, lecithin, minerals and secondary metabolites (phenolic and levo-dihydroxy-phenylalanine (L-DOPA), which is the precursor of the neurotransmitter dopamine and naturally found in seedlings, green pods and beans [5]). Broad bean seeds (cv. Giza 843, cv. Sakha 1 and cv. Giza 716) were obtained from one of the active breading programs directed by Prof. Dr. Esmat Waly and Prof. Dr. Saeyd Abdellah, Faculty of Agriculture, Assiut University, Egypt. The cultivation of plants started from 7 December 2018 to 7 May 2019. Broad bean seeds were surface sterilized by immersion in a mixture of ethanol $96 \%$ and $\mathrm{H}_{2} \mathrm{O}_{2}$ (1:1) for 3 minutes, followed by several washings with sterile distilled water. The concentrations of sewage sludge applications were prepared as follows:

Control: clay soil: was prepared by mix $100 \%$ clay soil $+0.0 \%$ sewage sludge.

$\star 20 \%$ sewage sludge: was prepared by mix $20 \%$ sewage sludge $+80 \%$ clay soil.

${ }^{\star} 50 \%$ sewage sludge: was prepared by mix $50 \%$ sewage sludge $+50 \%$ clay soil.

${ }^{\star} 70 \%$ sewage sludge: was prepared by mix $70 \%$ sewage sludge $+30 \%$ clay soil.

${ }^{\star} 100 \%$ sewage sludge: was prepared by mix $0.0 \%$ clay soil $+100 \%$ sewage sludge.

Ten seeds were sown per each pot. Each pot contained $3.6 \mathrm{~kg}$ of garden clay soil. All pots were irrigated with tap water for four weeks until full germination. After one month the pots were irrigated with the following Moheet drain water of the desired concentrations: $0.0 \%, 20 \%, 50 \%, 70 \%$ and $100 \%$ in each tested pots with the same concentrations of sewage sludge treatments and were classified into three groups.

\subsection{Sewage Treatment and Combined with IAA}

From three of previous groups which treated with different sewage concentrations $(0 \%, 20 \%, 50 \%, 70 \%$ and $100 \%)$, one group was sprayed by $200 \mathrm{ppm}$ of IAA, the other group was sprayed with $10 \mathrm{mM}$ of SA. In order to maintain the osmotic potential, the soil moisture content was kept near the field capacity using tap water. The seedlings were left to grow in natural conditions under these conditions for 150 days. At the end of the experimental period (5 months) yields of the pods were determined. 


\subsection{Laboratory Analysis for Metabolites}

To determine the dry matter yields of pods, they were dried in an oven at $80^{\circ} \mathrm{C}$. Successive weighting was carried out until the constant dry weight of each sample was reached. The soluble sugars were determined by the method of anthrone sulphoric acid which was stated by Fales (1951) [19]. The soluble proteins were determined according to the method adopted by Lowery et al. (1951) [20] and proline by Bates et al. (1973) [21].

\section{Statistical Analysis}

The triplicate sets of the experimental data for the different tested parameters were subjected to the one way analysis of variances (ANOVA) test in accordance with the experimental design using the SPSS program, version 13.0 and the means were compared using the least significant differences, L. S. D. at P levels of $0.05 \%$ (Steel, 1960) [22].

\section{Results}

\subsection{Growth Parameters as Affected by Sewage Sludge and Phytohormones Applications}

Fresh, dry matter and water content of pods in cv. 843 were significantly increased as increasing SSL with percent $137.2 \%, 204.9 \%$ and $191.2 \%$ at $100 \%$ level of SS (Table $1 \&$ Figure 1). Additionally, length and number of pods were became unchanged with increasing SSL treatments (Figure 2(a), Figure 2(b)). Increasing sewage sludge level application stimulated the production of fresh, dry matter and water content in pods of cv. Sakha 1 up to $70 \%$ SSL, after that, a sudden inhibition effect was induced (Table 1 \& Figure 1). The percent of increase was $183.2 \%, 199.0 \%$ and $169.6 \%$ at $70 \%$ SSL compared with control plants (Table 1 \& Figure 1). Correspondingly, length and number of pods in cv. Sakha 1 were increased with increasing SSL reached a maximum percent value at $70 \%$ SSL with percent $303 \%$ and $181.2 \%$ and then, a surprising reduction was induced at $100 \%$ SSL (Figure 2(a), Figure 2(b)). Fresh, dry matter and water content of pods in cv. 716 were significantly decreased as increasing SSL application with percent $32.5 \%, 42.3 \%$, and $29.4 \%$ at $100 \%$ level as compared with unsludge plants (Table 1). Additionally, length and number of pods were also reduced as elevating SSL treatment with percent $21.9 \%$ and $60.2 \%$ at $100 \%$ level (Figure 2(a), Figure 2(b)). Treatment cultivars Giza 843 and Sakha 1 with either IAA or SA induced a stimulation effect on fresh, dry matter, water content, number and length of pods especially at higher sewage sludge treatments (Table 1, Figure $1 \&$ Figure 2(a), Figure 2(b)). This effect was more pronounced in Sakha 1 cultivar than cv. Giza 843. Phytohotmonal application was generally enhanced the production of fresh, dry matter, water content, length and number of pods in cv. Giza 716 at 50\% to $100 \%$ sludge application when compared with non-hormonal plants treatments (Table 1, Figure 2(a), Figure 2(b)). This stimulation trend was more pronounced at IAA than SA application and at higher SSL. 


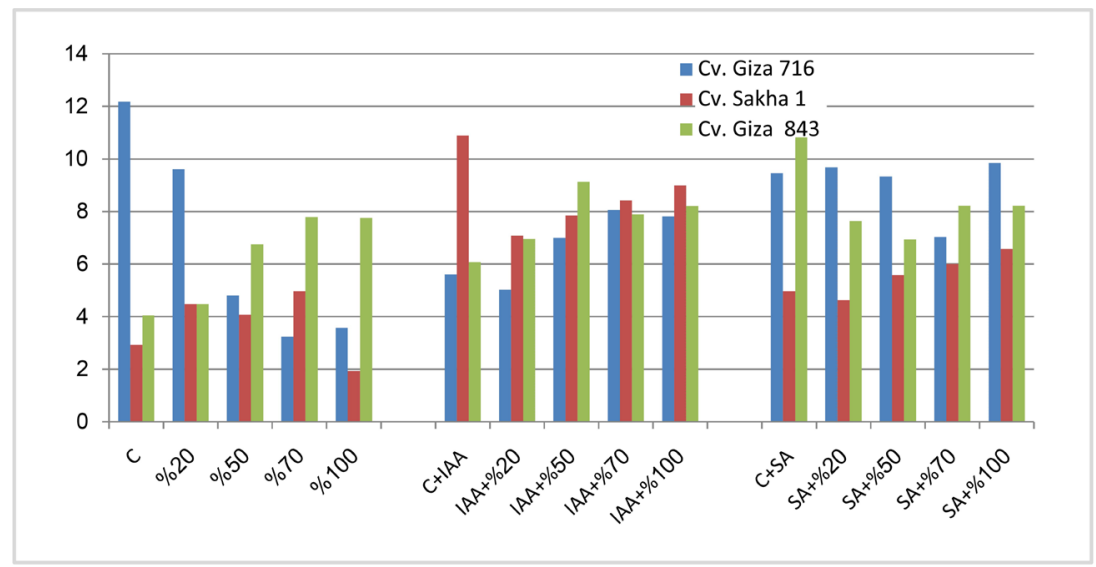

Figure 1. Interactive effect of sewage sludge and phtohormones (IAA or SA) on water content in pods of Giza 843, Sakha 1 and Giza 716 cultivars.

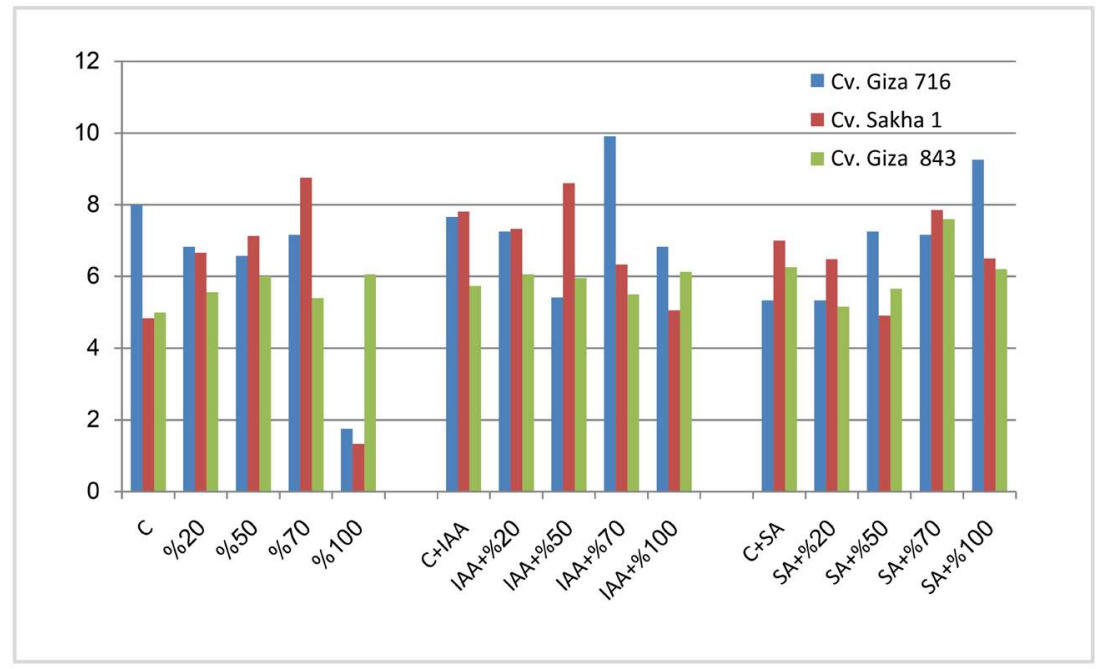

(a)

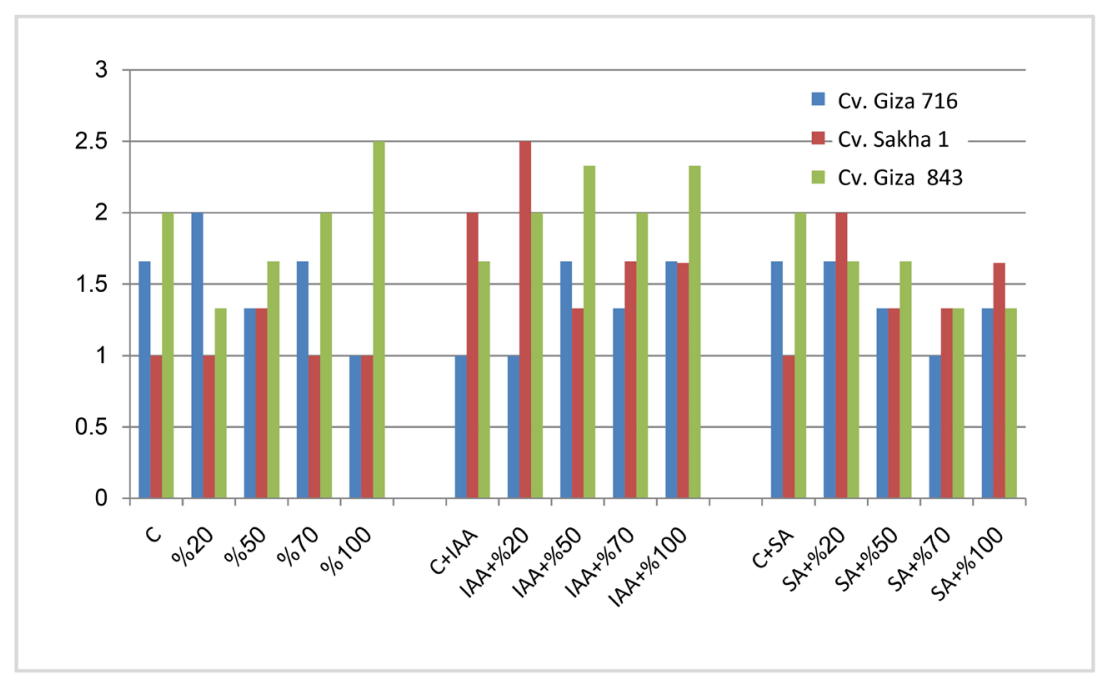

(b)

Figure 2. Interactive effect of sewage sludge and phtohormones (IAA or SA) on length (a) and number (b) in pods of Giza 843, Sakha 1 and Giza 716 cultivars. 
Table 1. Effect of different sewage sludge levels and interaction with IAA or SA treatments on fresh and dry matter in pods of broad bean cultivars Giza 843, Sakha 1 and Giza 716.

\begin{tabular}{|c|c|c|c|c|c|c|c|c|c|c|c|c|}
\hline \multirow{2}{*}{$\begin{array}{l}\text { Treatment } \\
\text { SS levels }\end{array}$} & \multicolumn{4}{|c|}{ Cv. Giza 843} & \multicolumn{4}{|c|}{ Cv. Sakha 1} & \multicolumn{4}{|c|}{ Cv. 716} \\
\hline & F. m. & $\%$ & D. M. & $\%$ & F. M. & $\%$ & D. $m$. & $\%$ & F. m. & $\%$ & D. m. & $\%$ \\
\hline $\mathrm{C}$ & 4.9 & 100 & 0.856 & 100 & 4.49 & 100 & 1.56 & 100 & 15.1 & 100 & 2.9 & 100 \\
\hline $20 \%$ & 6.0 & 147.6 & 1.20 & 140.2 & 6.51 & 144.9 & 2.03 & 130.1 & 11.6 & 76.8 & 2.0 & 68.9 \\
\hline $50 \%$ & 8.7 & 177.8 & 1.98 & 231.3 & 6.59 & 146.8 & 2.51 & 160.9 & 5.9 & 39.1 & 1.1 & 37.9 \\
\hline $70 \%$ & 10.4 & 211.2 & 2.6 & 3.1 .4 & 8.08 & 179.9 & 3.11 & 199.3 & 4.7 & 31.1 & 1.5 & 51.7 \\
\hline $100 \%$ & 9.92 & 202 & 2.2 & 252.3 & 2.27 & 50.7 & 0.33 & 21.1 & 4.5 & 29.8 & 0.95 & 32.7 \\
\hline $\mathrm{C}+\mathrm{IAA}$ & 7.54 & 153.6 & 1.5 & 171.7 & 13.7 & 305.1 & 2.78 & 187.9 & 6.9 & 45.7 & 1.3 & 44.8 \\
\hline $20 \%+$ IAA & 9.08 & 148.9 & 2.1 & 248.8 & 10.3 & 229.4 & 3.21 & 115.4 & 6.7 & 44.4 & 1.7 & 58.6 \\
\hline $50 \%+$ IAA & 11.8 & 241.9 & 2.7 & 320 & 12.7 & 282.8 & 4.82 & 308.9 & 8.6 & 56.9 & 1.5 & 51.2 \\
\hline $70 \%+$ IAA & 10.7 & 218.4 & 2.8 & 327.1 & 11.5 & 256.1 & 3.11 & 199.3 & 9.8 & 64.9 & 1.8 & 62.1 \\
\hline $100 \%+\mathrm{IAA}$ & 10.4 & 211.8 & 2.2 & 257.0 & 10.4 & 231.6 & 1.40 & 89.7 & 9.77 & 64.7 & 1.9 & 65.5 \\
\hline $\mathrm{C}+\mathrm{SA}$ & 13.8 & 281 & 2.98 & 348.1 & 6.5 & 144.8 & 1.52 & 97.4 & 11.3 & 74.8 & 1.9 & 65.5 \\
\hline $20 \%+\mathrm{SA}$ & 10.5 & 213.8 & 2.9 & 334.1 & 10.5 & 233.8 & 2.86 & 183.3 & 11.6 & 76.8 & 1.9 & 65.5 \\
\hline $50 \%+\mathrm{SA}$ & 9.1 & 84.5 & 2.1 & 247.6 & 9.0 & 200.4 & 3.42 & 219.2 & 11.4 & 75.5 & 2.6 & 89.7 \\
\hline $70 \%+$ SA & 11.1 & 225.9 & 2.9 & 335.3 & 9.9 & 220.5 & 3.79 & 242.9 & 11.9 & 79.1 & 2.6 & 89.7 \\
\hline $100 \%+\mathrm{SA}$ & 4.9 & 100 & 0.856 & 100 & 8.4 & 187.1 & 1.83 & 117.3 & 12.5 & 82.8 & 2.7 & 93.1 \\
\hline L. S. D. $0.05 \%$ & \multicolumn{2}{|c|}{0.95} & \multicolumn{2}{|c|}{1.20} & \multicolumn{2}{|c|}{0.95} & \multicolumn{2}{|c|}{0.87} & \multicolumn{2}{|c|}{0.65} & \multicolumn{2}{|c|}{0.88} \\
\hline
\end{tabular}

The mean difference is significant at the $0.05 \%$ level.

\subsection{Metabolites as Affected by Sewage Sludge and Phytohormones Applications}

Soluble sugar and soluble protein contents were decreased as increasing SSL in both cv. Sakha 1 and cv. Giza 716 (Table 2). However, in cv. Giza 843 soluble sugar was significantly increased, soluble protein was markedly decreased as increasing SSL (Table 2). Proline content showed a variable response in the three tested cultivars, while became unchanged in cv. Sakha 1, significantly increased in cv. Giza 716 and markedly decreased in cv. Giza 843 compared with control plants (Table 2). IAA treatments induced mostly unchanged effect in soluble sugar, soluble protein and proline contents in three tested cultivars. Except for this trend there was an increasing effect in soluble sugar and proline content in cv. Giza 843 and soluble sugar and protein in cv. Sakha 1 at 50\% and $70 \%$ SSL only. On the other side, sewage sludge exhibited a marked reduction in the accumulation of proline in cv. Sakha 1. Application of SA with sewage sludge treatments induced mostly unchanged effect or tended to decrease in soluble sugar, soluble protein and proline contents in three broad bean cultivars (Table 2). Excluding for this pattern there was an accumulation trend in soluble sugar in cv. Sakha 1 and proline in both cultivars Giza 843 and Giza 716 (Table 2). 
Table 2. Effect of different sewage sludge levels and interaction with IAA or SA treatments on soluble sugar (mg.g $\left.\mathrm{g}^{-1} \mathrm{~d} . \mathrm{m}.\right)$, soluble

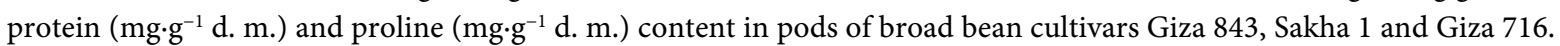

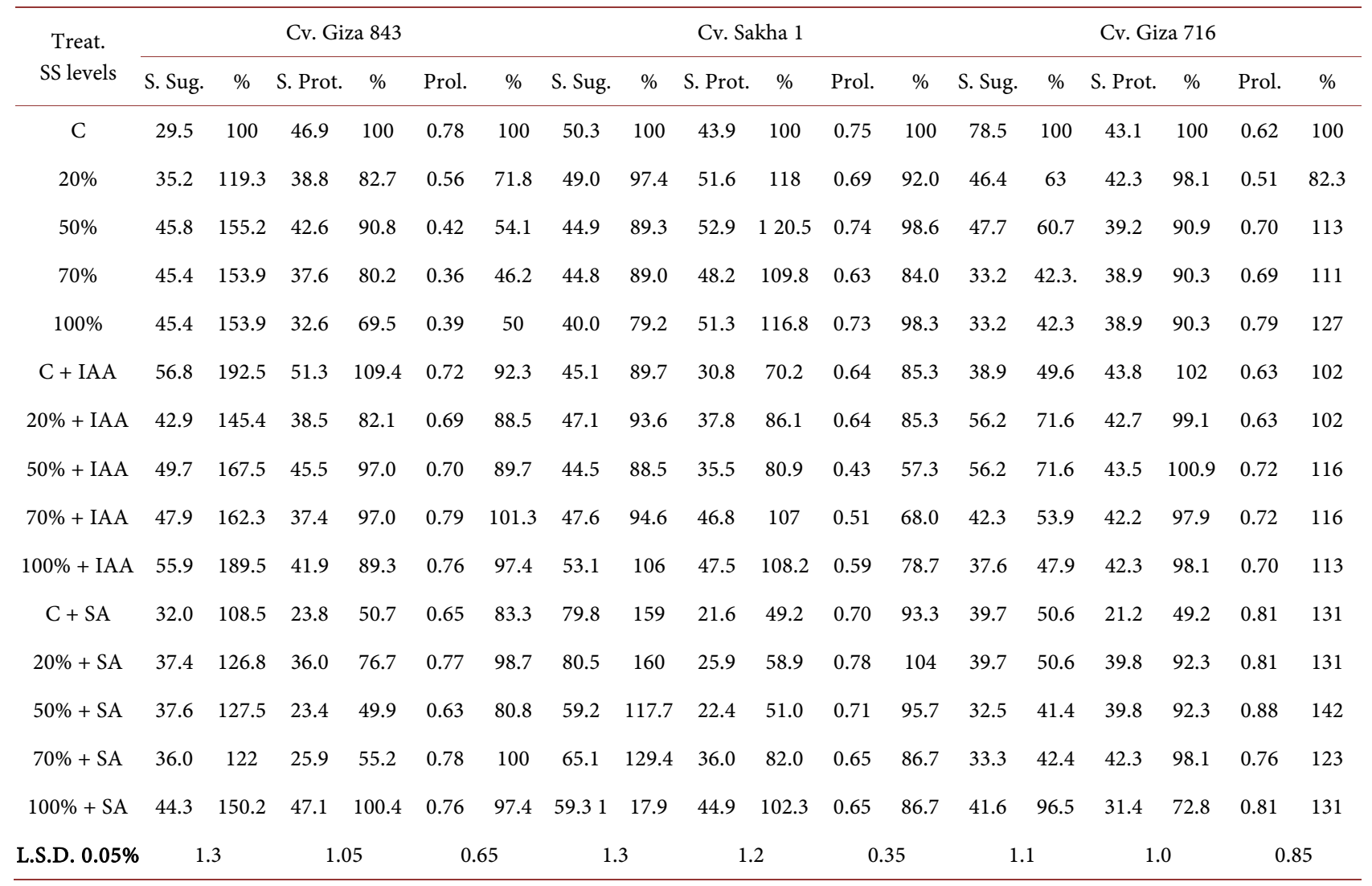

The mean difference is significant at the $0.05 \%$ level.

\subsection{Micronutrient as Sewage Sludge and Phytohormones Applications}

In cv. Giza 843, sewage sludge application with $100 \%$ level illustrated no marked change in $\mathrm{Zn}$ while a slight increase in $\mathrm{Ni}$ content was detected (Figure 3(a)). However, a huge reduction was observed in the accumulation of both $\mathrm{Pb}$ and $\mathrm{Cu}$ which reached to over a half value in relation with their control. No marked change in the accumulation of $\mathrm{Zn}$ and $\mathrm{Ni}$ was observed in plants grown with SS plus IAA treatment (Figure 3(a)). On the other hand, $\mathrm{Pb}$ and $\mathrm{Cu}$ ranked against each other, while $\mathrm{Pb}$ was markedly decreased, $\mathrm{Cu}$ was markedly increased reached $0.861 \mathrm{mg} / \mathrm{g}$. d. m. in relation with its control $0.339 \mathrm{mg} / \mathrm{g} \mathrm{d}$. m. Plants of cv. Giza 843 grown under SS plus SA exhibited a significant reduction in the contents of $\mathrm{Zn}, \mathrm{Pb}$ and $\mathrm{Cu}$. Except Ni showed a smooth increase in relation with control plants (Figure 3(a)). Sludge application decreased the contents of $\mathrm{Cu}, \mathrm{Pb}, \mathrm{Ni}$ and $\mathrm{Zn}$ in pods of Sakha 1 (Figure 3(b)). Treatment cv. Sakha 1 plants grown at 100\% SSL plus IAA was markedly increased all tested minerals $(\mathrm{Cu}, \mathrm{Pb}, \mathrm{Ni}$, and $\mathrm{Zn})$ compared with sludge treatment. Plants treated with SS plus SA showed an increasing effect in the accumulation of both $\mathrm{Zn}$ and $\mathrm{Ni}$, while exhibited a reduction in $\mathrm{Pb}$ (which reached a $0.04 \mathrm{mg} / \mathrm{g} \mathrm{d}$. $\mathrm{m}$. in relation with control $0.068 \mathrm{mg} / \mathrm{g} \mathrm{d}$. $\mathrm{m}$.) and $\mathrm{Cu}$ (which reached a $0.204 \mathrm{mg} / \mathrm{g} \mathrm{d}$. m. in relation with control $0.229 \mathrm{mg} / \mathrm{g} \mathrm{d}$. m.) (Figure 3(b)). Sludge 


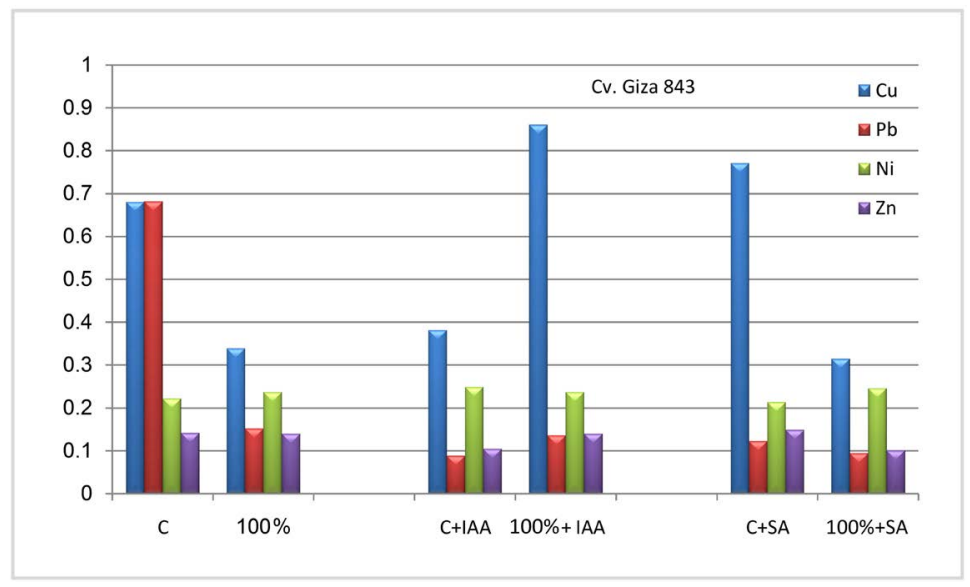

(a)

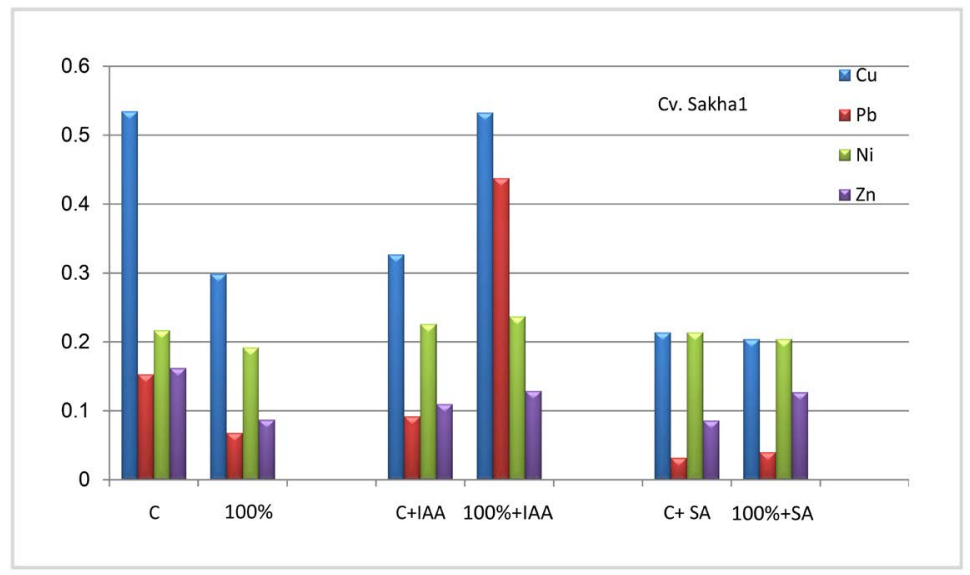

(b)

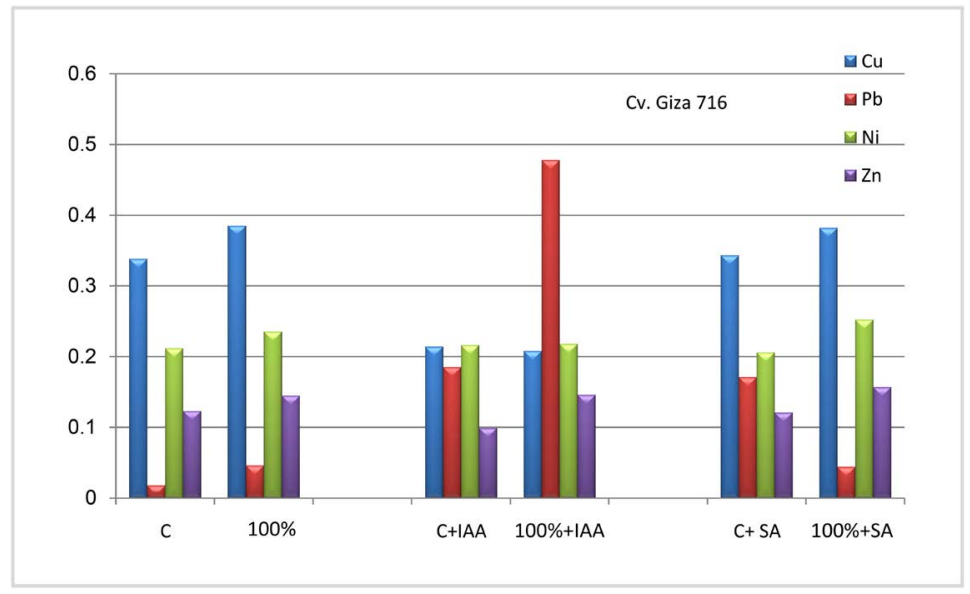

(c)

Figure 3. Interactive effect of sewage sludge and phtohormones (IAA or $\mathrm{SA}$ ) on $\mathrm{Cu}, \mathrm{Pb}, \mathrm{Ni}$ and $\mathrm{Zn}$ contents of pods in cultivars Giza $843 \mathrm{~A}$, Sakha 1 $B$ and Giza 716 C.

application with $100 \%$ level induced in cv. Giza 716 an increasing effect in the accumulation of $\mathrm{Ni}, \mathrm{Zn}, \mathrm{Pb}$ and $\mathrm{Cu}$ (Figure $3(\mathrm{c})$ ). The most increasing effect was recorded in the accumulation of $\mathrm{Pb}$ which reached $0.046 \mathrm{mg} / \mathrm{g} \mathrm{d} . \mathrm{m}$. in rela- 
tion with control $0.018 \mathrm{mg} / \mathrm{g} \mathrm{d}$. $\mathrm{m}$. The contents of $\mathrm{Zn}$ became more or less unchanged while a slight reduction was induced in the accumulation of $\mathrm{Ni}$ and $\mathrm{Cu}$ in cv. Giza 716 treated with SS plus IAA (Figure 3(c)). On the other side, a huge accumulation of $\mathrm{Pb}$ reached $0.478 \mathrm{mg} / \mathrm{g}$. d. $\mathrm{m}$. in relation with control 0.046 $\mathrm{mg} / \mathrm{g} \mathrm{d}$. m. under $100 \%$ SS plus IAA treatment. Cv. Giza 716 treated with SS plus SA induced an increasing effect in both $\mathrm{Zn}$ and $\mathrm{Ni}$ while, unchanged effect was recorded in both $\mathrm{Pb}$ and $\mathrm{Cu}$ (Figure 3(c)).

\section{Discussion}

From the present results it can be demonstrated a variable response of three broad bean cultivars to increase sewage sludge levels. While both cultivars Sakha 1 and Giza 843 responses positively to increase SSL, cv. 716 responses negatively to these treatments. According to this response can be arranged broad bean cultivars in the following rank cv. Giza 843 followed by cv. Sakha 1 followed by cv. 716. Fresh, dry matter, water content, length and number of pods in cv. Giza 843 at all SSL and in cv. Sakha 1 up to 70\% SSL were increased. Here sewage sludge acts as a biofertilizer. Sludge may constitute an upright fertilizer as it is a good source of phosphorus $(\mathrm{P})$, nitrogen $(\mathrm{N})$, organic matter, and micronutrients [23] [24] [25] [26] [27]. Correspondingly, Mazen et al., (2010) and Abdel Latef et al. (2015) [28] [29] showed an increase in growth parameters (fresh, dry matter and pigments) with sludge applications. Additionally, Urbaniak et al. (2017) [30] showed that increase willow (Salix sp.) biomass, leaf length and Chl. a and $b$ contents and a decline in detoxifying enzyme under sewage sludge treatments. Wyriwicka et al. (2018) [31] explained that willow biomass by reading good conditions for plant growth associated with protection against oxidative damage, efficient functioning of antioxidant system and maintain of osmotic balance, the soil environment and plant roots, reduction of lipid peroxides in leaves and roots CAT activity increase and proline in roots. However, sewage sludge application can establish a threat to the environment because of its relatively high HMs concentration. It is worthy to note that in cv. Sakha 1 sewage sludge application up to $70 \%$ exhibited an stimulation in growth parameters while at $100 \%$ level a significant inhibition was recorded. This may be due to the addition of common clay soil to sewage sludge diminished the drastic effect of toxic compounds.

The present data were recorded that a lowering effect in production of fresh dry, matter and water content in cv. Giza 716 with SSL applications. This supported by studies that have been cited by Singh and Agrawal (2008) [32] emphasized negative effects of these toxic elements on growth of plant, groundwater value, and long-term soil fertility. Faced with this problem, it is necessary to explore the risks and benefits provided to authorize or not the SS spreading on forest parcels. Sludge application was markedly decreased $\mathrm{Cu}, \mathrm{Pb}, \mathrm{Ni}$ and $\mathrm{Zn}$ in relation with control in both cv. Giza 843 and cv. Sakha 1. This reduction was more prominent in case of $\mathrm{Cu}$ and $\mathrm{Pb}$ which reached a half-value than control 
plant. This reduction in heavy metals concentrations was associated with increase of fresh, dry matter, water content, length and number of pods which reflected on the lowering toxic effects on plant metabolism. On the other side, in $\mathrm{cv}$. Giza 716, there is an increase in the accumulation of $\mathrm{Cu}, \mathrm{Pb}, \mathrm{Ni}$ and $\mathrm{Zn}$ in relation with control with sludge sewage application. This is concomitant with inhibition in fresh, dry matter, water content length, and number of pods and increasing damaging effects of heavy metals. Most of the studies were devoted to follow up the outcome of high concentrations of metals when sewage sludge was applied [33]. The use of sludge in agriculture within the European Union (EU) is now synchronized only by the limits of heavy metals $(\mathrm{Cd}, \mathrm{Cu}, \mathrm{Hg}, \mathrm{Ni}, \mathrm{Pb}$ and Zn) listed in Council Directive 86/278/EEC. Directive was to encourage the safe use of sewage sludge in agriculture in order to prevent damaging effects on soil and transference to plants, animals and humans. Several European countries moreover forced more stringent. Directives and laws and set restrictions for concentrations of other heavy metals. The most public additional limit is set for chromium [34]. In cv. Giza 843, Zn and Ni became unchanged with sewage sludge plus IAA treatments, while there is a huge reduction in $\mathrm{Pb}$, an opposite trend was observed in $\mathrm{Cu}$ increased in both control and with sludge treatments. On the other hand, plants sprayed with SA significantly decreased $\mathrm{Zn}, \mathrm{Pb}$ and $\mathrm{Cu}$ with sewage sludge applications. In $\mathrm{cv}$. Sakha 1 , the contents of $\mathrm{Cu}$ and $\mathrm{Pb}$ were decreased with SS plus SA and with control plants, while Ni and $\mathrm{Zn}$ were slightly increased. In plant treated with SS plus IAA increased all tested heavy metals $(\mathrm{Cu}, \mathrm{Pb}, \mathrm{Ni}$ and $\mathrm{Zn})$ especially $\mathrm{Cu}$ and in $\mathrm{Pb}$ which reached 4-fold than corresponding levels. In cv. Giza 716, SS plus IAA decreased $\mathrm{Cu}$ and $\mathrm{Ni}$ in both control and SS treatments, while increased $\mathrm{Pb}$ in both control and in sludge applications which reached 100 -fold than reference control. Plant exposed to SS plus SA applications induced an increasing in $\mathrm{Zn}$ and Ni heavy metals in both control and SS applications. The mechanism of tolerant strategy in response to sewage sludge application was variable between different tested cultivars. So, the increase in soluble sugar in cv. Giza 843 and soluble protein in cv. Sakha 1 which concomitant with the enhancement effect of sewage sludge as fertilizer in dry matter production of these two cultivars and increase their tolerance. While the sensitivity in pods of $\mathrm{cv}$. Giza 716 was related with reduction in soluble sugar and soluble protein which reflected in lowering dry matter production. El-Tayeh et al. (2011) [24] showed highest dry matter was detailed by application of sewage sludge. Soluble sugar and proteins improved in roots while soluble protein reduced in shoots by increasing sewage sludge at 30\% level. Mazen et al., (2010) [28] was illustrated that generally adding sewage sludge to soil enhanced soil texture raised organic matter contents, total sugar and proteins. Wyriwicka et al. (2019), [35] showed that cucumber plants grown in sewage sludge rise soluble protein. Application of SS to forest plantations could potentially increase tree growth and wood making and improve several soil features [36]. Abdel Latef et al. (2015) [29] stated that sewage sludge applications effect on biochemical anal- 
ysis (sugar, protein, free amino acids, and proline and antioxidant enzymes activity) of maize plants. Dar et al. (2018) [26] illustrated that sugar and protein of Brassica juncea improved as increasing sludge submissions. Proline has different roles in plant metabolism, became unchanged in cv. Sakha 1 while a reduction was recorded in cv. Giza 843. This indicated that proline has not any significant role in cv. Sakha 1. While in cv. Giza 843, proline reduction was contributed in increasing its tolerant to sewage sludge application, here proline cannot consider as a sign of stress. On the other side proline tended to increase in cultivar $\mathrm{cv}$. Sakha 1 which indicating that proline acts as a sign of stress. The increasing trend in the accumulation of proline in Brassica juncea under sewage sludge treatments was detected by Dar et al. (2018) [26]. Martins et al. (2016) [37] suggested that regardless of the benefits of using sewage sludge as organic compost, can induce genetic injury in plants. The potential risks to health products after the intake of food cultivated in sewage sludge-amended soils. Sewage sludge comprises compounds which could be damaging to the ecosystem such as heavy metals, organic pollutants and pathogens [38]. IAA treatment increased soluble sugar and proline in cv. Giza 843, soluble sugar and protein in cv. Sakha at higher SSL (70\% and 100\%) and mostly in cv. Giza 716. Additionally, SA treatments induced an increasing effect in soluble sugar in cv. Sakha 1 while increasing effect in the accumulation of proline content in both cultivars 716 and Giza 843 which reached at the later obove 2 -fold as compared with corresponding control plants. Bucker-Neto et al. (2017) [17] has prolonged view of how plant hormones can adjust and assimilate growth responses to various environmental cues to sustain life. The role of ABA, auxin, brassinosteriod and ethylene in signaling pathways defense mechanisms and mitigation of heavy metal toxicity was investigated. Heavy metal affects on auxin metabolism, exogenous IAA can release endogenous levels of auxin that rise root biomass [39]. Counteraction of IAA and heavy metal can used as protective mechanism against poisonousness in crop plants or as useful tools in phytoremediation programs for detoxification of polluted areas [40]. Sakr et al. (2012) [41] were indicated that ascorbic acid, salicylic acid, yeast extract, thyme oil and mycorrhizal inoculation had useful effect established by minting yield and decreasing heavy metal uptake as well as elevating stress-related metabolites as phenols. Salicylic acid is a universal plant phenolic compound that has been used in many plant species to relieve heavy metal toxicity by directive plant growth, reducing heavy metal uptake and scattering in plants, protecting membrane integrity and stability, scavenging reactive oxygen species and improving antioxidant defense system and positive photosynthetic capacity. SA functions as significant molecule involved in several important genes expression [42] [43] [44]. Sharma et al. (2020) [45] was illustrated that SA interacts with other plant hormones (auxin, abscisic acid and gibberellins) and encourages the stimulation of antioxidant compounds and enzymes thereby changing heavy metal treated plants and helping in counteraction heavy metal stress. 
Therefore, the strategy mechanisms in response broad bean cultivars to sewage sludge treatments were different and phtohormones applications had a positive effect in alleviation sewage sludge effect.

\section{Conflicts of Interest}

The authors declare no conflicts of interest regarding the publication of this paper.

\section{References}

[1] Abdel-Dayem, S. (2011) Water Quality Management in Egypt. International Journal of Water Resources Development, 27, 181-202. https://researchgate.net https://doi.org/10.1080/07900627.2010.531522

[2] El Kashouty, M., El Sayed, E. and Kamel, A.A. (2012) The Hydroemical Characterisitcs and Evolution of Groundwater and Surface Water in the Western Part of the River Nile, El-Minia District, Upper Egypt. Arabian Journal of Geosciences, 5, 637-652. https://www.readucbe.com/articles/10.1007/s12517-010.021 https://doi.org/10.1007/s12517-010-0219-x

[3] Melegy, A., El-Kammar, A., Yehia, M.M. and Miro, G. (2013) Hydrogeochemical Characteristics and Assessment of Water Resources in Beni Suef Governorate, Egypt. Open Journal of Ecology, 4, 44-57. https://www.researchgate.net

[4] Abou Heleika, A., Ismail, E. and Ahmed, M. (2018) Delineation of Contamination Using Geophysical and Hydrogeochemical Methods around the El Moheet Drain in the El Minia District, Upper Egypt. Arabian Journal of Geoscience, 11, 625. https://doi.org/10.1007/s12517-018-3927-2

[5] Abd El-Samad, H.M., Shaddad, M.A.K. and Abd El-Hakeem, N.K. (2019) Combined Action of Cupper with IAA on Individual Amino Acids and Microelement in Pods of Two Broad Bean Cultivars. American Journal of Plant Sciences, 10, 670-697.

https://www.scirp.org/journal/ajps https://doi.org/10.4236/ajps.2019.104049

[6] Zhang, Y., Sallach, J.B., Hodges, L., Snow, D.D., Bartelt-Hunt, S.L., Eskridge, K.M. and Li, X. (2016) Effects of Soil Texture and Drought Stress on the Uptake of Antibiotics and the Internalization of Salmonella in Lettuce Following Wastewater Irrigation. Environmental Pollution, 208, 523-531. http://www.researchgate.net https://doi.org/10.1016/j.envpol.2015.10.025

[7] Turek, A., Wieczorek, K. and Wolf, W.M. (2019) Digestion Procedure and Determination of Heavy Metals in Sewage Sludge-An Analytic Problem. Sustainability, 11, 17553. https://doi.org/10.3390/su11061753

[8] Tytła, M., Widziewicz, K. and Zielewicz, Z. (2016) Heavy Metals and Its Chemical Speciation in Sewage Sludge at Different Stages of Processing. Environmental Technology, 37, 899-908. https://doi.org/10.1080/09593330.2015.1090482

[9] Duan, B., Zhang, W., Zheng, H., Wu, C., Zhang, Q. and Bu, Y. (2018) Disposal Situation of Sewage Sludge from Municipal Wastewater Treatment Plants (WWTPs) and Assessment of the Ecological Risk of Heavy Metals for Its Land Use in Shanxi, China. International Journal of Environmental Research and Public Health, 14, 823. http://wwpi.com/joursl/ijerphw.md https://doi.org/10.3390/ijerph14070823

[10] Cantinho, P., Matos, M., Trancoso, M.A. and Correia dos Santos, M.M. (2016) Behaviour and Fate of Metals in Urban Wastewater Treatment Plants: A Review. International Journal of Environmental Science and Technology, 13, 359-386. 
https://www.springer.com/journal/13762

https://doi.org/10.1007/s13762-015-0887-x

[11] Duan, B., Zhang, W., Zheng, H., Wu, C., Zhang, Q. and Bu, Y. (2017) Comparison of Health Risk Assessments of Heavy Metals and as in Sewage Sludge from Wastewater Treatment Plants (WWTPs) for Adults and Children in the Urban District of Taiyuan, China. International Journal of Environmental Research and Public Health, 14, 1194. https://doi.org/10.3390/ijerph14101194

[12] Milik, J.K., Pasela, R., Lachowicz, M. and Chalamonski, M. (2017) The Concentration of Trace Elements in Sewage Sludge from Wastewater Treatment Plant in Gniewino. JEE, 18, 118-124. https://doi.org/10.12911/22998993/74628

[13] Zeid, I.M. and Abou El Ghate, H.M. (2007) Effect of Sewage Water on Growth, Metabolism and Yield of Bean. Journal of Biological Sciences, 7, 34-40. https://scialert.net/fulltextmobile/?doi=jbs.2007.34.40

[14] Bourioug, M., Alaoui-Sossé, L., Laffray, X., Raouf, N., Benbrahim, M., Badot, P.M. and Alaoui-Sossé, B. (2014) Evaluation of Sewage Sludge Effects on Soil Properties, Plant Growth, Mineral Nutrition State, and Heavy Metal Distribution in European Larch Seedlings (Larix decidua). Arabian Journal for Science and Engineering, 39, 5325-5335. https://www.springer.com/journal/13369 https://doi.org/10.1007/s13369-014-1100-0

[15] Wojinarowicz, P., Wang, W., Zhou, H., Parker, W.J. and Helbing, C.C. (2014) Increasing Activities of Municipal Wastewater in a Covetional Activated Sludge Wastewater Treatment Plant. Water Research, 1, 265-272. https://doi.org/10.1016/j.watres.2014.08.035

[16] Klimas, E., Pulikowska, A.S., Gorka, B. and Wileczorek, P. (2016) Presence of Plant Hormones in Composts Made from Organic Fractions of Municipal Solid Waste. Journal of Elementology, 21, 1043-1053. https://www.agro.icm.edu.pl>element

[17] Bucker-Neto, L., Paiva, A.L.S., Machado, R.D., Arenhart, R.A. and Pinheiro, M.M. (2017) Interactions between Plant Hormones and Heavy Metals Responses. Genetics and Molecular Biology, 40, 373-386. https://doi.org/10.1590/1678-4685-gmb-2016-0087

[18] Tytla, M. (2019) Assessment of Heavy Metal Pollution and Potential Ecological Risk in Sewage Sludge from Municipal Waste Water Treatment Plant Located in the Most Industrialized Region in Poland-Case Study. International Journal of Environmental Research and Public Health, 16, 2430-2445.

https://www.mdpi.com/1660-4601/16/13 https://doi.org/10.3390/ijerph16132430

[19] Fales, F.W. (1951) The Assimilation and Degradation of Carbohydrates of Yeast Cells. Journal of Biological Chemistry, 193, 113-118. http://www.jbc.org/content/193/1/113.full.pdf

[20] Lowry, O.H., Roserbrogh, N.J., Farr, L. and Ramadal, R.J. (1951) Protein Measurement with the Folin-Phenole Reagent. Journal of Biological Chemistry, 193, 265-275. http://en.wikipedia.org/wiki/Journal of Biological Chemistry

[21] Bates, L.W., Waldern, R.P. and Teare, I.D. (1973) Rapid Determination of Free Proline Foe Water Stress. Plant Soil, 39, 205-207. https://doi.org/10.1007/BF00018060 https://link.spriger.content/article/10.1007/BF00018060

[22] Steel, R.G. and Torrie, J.H. (1960) Principles and Procedures of Statistics. McGraw-Hill Book Co., New York. http://garfield.library.upenn.edu/classics1977/A1977DU23500002

[23] Bramryd, T. (2001) Effects of Liquid and Dewatered Sewage Sludge Applied to a 
Scots Pine Stand (Pinus sylvestris L.) in Central Sweden. Forest Ecology and Management, 147, 197-216. https://portal.research.lu.se/portal/en/publications/ https://doi.org/10.1016/S0378-1127(00)00476-X

[24] El-Tayeh, N.A. (2011) Effect of Sewage Sludge Amendment on Some Growth Parameters in Cotton Plants. In AGRIS Science, 40, 47-60. https://agris.fao.org/agrissearch/search.do?recordID--EG2013000076

[25] Tytla, M. (2018) The Effects of Ultrasonic Disintegration as Function of Waste Activated Sludge Characteristics and Technical Conditions of Conducting the Processes-Comprehensive Analysis. International Journal Research Public Health, 15, 2311. https://pubmed.ncbi.nlm.nih.gov/30347832/ https://doi.org/10.3390/ijerph15102311

[26] Dar, M.I., Naikoo, M.I., Khan, F.A. and Green, I.D. (2018) Assessing the Feasibility of Sewage Sludge Applications for the Cultivation of Brassica juncea L.: Metal Accumulation, Growth, Biochemical and Yield Responses. Journal Environmental Science and Renewable Resources, 1, 104. https://elynsgroup.com https://www.semanticscholar.org

[27] Kosowski, P., Szostek, M., Pieniazek, R., Antos, P., Skrobacz, K., Piechowiak, T., Azczek, A., Jozefczyk, R. and Balawejder, M. (2020) New Approach for Sewage Sludge Stabilization with a Zone. Sustainability, 12, 886. https://www.mdpi.com/2071-1050/123/886 https://www.mdpi.com https://doi.org/10.3390/su12030886

[28] Mazen, A., Faheed, F. and Ahmed, A. (2010) Study of Potential Impacts of Using Sewage Sludge in the Amendment of Desert Reclaimed Soil on Wheat and Jews Mallow Plants. Brazilian Archives of Biology and Technology, 53, 917-930. https://www.scielo.br/scielo.ph?script=sci-arttex\&pid=s1516-89132010000400022\&I ng=en\&nrm=150\&lng=en https://doi.org/10.1590/S1516-89132010000400022

[29] Abdel Latef, A.A. and Sallam, M.M. (2015) Changes in Growth and Some Biochemical Parameters of Maize Plants Irrigated with Sewage Water. Austin Journal of Plant Biology, 1, 1004. https://www.austinpuplishinggroup.com/

[30] Urbaniak, M., Wyrwicka, A., Toloczko, W., Serwecinska, L. and Zielinsko, M. (2017) The Effect of Sewage Sludge Application on Soil Properties and Allow (Salix sp.) Cultivation. Science of the Total Environment, 586, 66-75.

https://www//researchgate.net3136 https://doi.org/10.1016/j.scitotenv.2017.02.012

[31] Wyrwicka, A. and Urbaniak, M. (2018) The Biochemical Response of Willow Plants (Salix viminalis L.) to the Use of Sewage Sludge from Varios Size of Wastewater Treatment Plant. Science of the Total Environment, 615, 882-894. https://www.journals.elsevier.com/science-of-the-evironment https://doi.org/10.1016/j.scitotenv.2017.10.005

[32] Singh, R.P. and Agrawal, M. (2008) Potential Benefits and Risks of Land Application of Sewage Sludge. Waste Management, 28, 347-358. https://www.sciencedirect.com/science/article/pii/s0956053x07000/41 https://doi.org/10.1016/j.wasman.2006.12.010

[33] Galal, Y.G.M. (2012) Recycling of Treated Sewage Sludge in Sustainable Agriculture. Arab Journal of Nuclear Sciences and Applications, 45, 548-560. http://www.esnsa.eg.com/

[34] Hudcova, H., Vymazal, J. and Rozkosny, M. (2019) Present Restrictions of Sewage Sludge Application in Agriculture within the European Union. Soil and Water Re- 
search, 14, 104-120. https://www.doi.org/10.17221/36/2018.SWR https://doi.org/10.17221/36/2018-SWR

[35] Wyrwicka, A., Urbaniak, M. and Przybylisk, M. (2019) The Response of Cucumber Plants (Cumcumis sativus L.) to the Application of PCB Contaminated Sewage Sludge and Urban Sediment. PeerJ., 7, e6743. https://peerj.com/articles/6743/

[36] Mosquera-Losada, M.R., Lopez-Diaz, L. and Rigueiro-Rodriguez, A. (2008) Sewage Sludge Fertilization of a Silvopastoral System with Pines in Northwestern Spain. Agroforestry Systems, 53, 1-10. https://www.researchgate.net\%3E2252/

[37] Martins, M.N.C., Souza, V.V. and Souza, T.D. (2016) Genotoxic and Mutagenic Effects of Sewage Sludge on Higher Plants. Ecotoxicology and Environmental Safety, 124, 489-496. https://www.researhgate.net/publication/286199104 https://doi.org/10.1016/j.ecoenv.2015.11.031

[38] Lamastra, L., Suciu, N.A. and Trevisan, M. (2018) Sewage Sludge for Sustainable Agriculture: Contaminants Content and Potential Use as Fertilizer. Chemical and Biological Technologies in Agriculture, 5, Article No. 10. https://ink.springer.com/article/10.1186/s540538-0122-3 https://doi.org/10.1186/s40538-018-0122-3

[39] Liphadzi, M.S., Kirkham, M.B. and Paulsen, G.M. (2006) Auxin Enhanced Root Growth for Amended Soil. Environmental Technology, 27, 695-704.

https://www.researchgate.net/publication https://doi.org/10.1080/09593332708618683

[40] Tandon, S.A., Kumar, R. and Parsana, S. (2015) Auxin Treatment of Wetland and Non-Wetland Plant Species to Enhance Their Phytoremediation Efficiency to Treat Municipal Wastewater. Journal of Scientific and Industrial Research, 74, 702-707. http://www.sernanticscholar.org/paper/

[41] Sakr, M.T., Darwish, M.M., Ibrahim, H.M. and Mostafa, N.A. (2012) Effect of Ascorbic Acid, Salicylic Acid, Yeast Extract, Thyme Oil and Mycorrhizal Inoculation on Heavy Metal-Affected or Sewage Sludge-Amended Soybean Plants. Journal of Plant Production Mansoura University, 3, 2223-22235.

https://jpp.journal.ekb.eg/issue 12725 12800-html https://doi.org/10.21608/jpp.2012.84895

[42] Liu, Z., Ding, Y., Wang, F., Ye, Y. and Zhu, C. (2016) Role of Salicylic Acid in Resistance to Cadmium Stress in Plant. Plant Cell Reports, 35, 719-731.

https://www.pubmed.ncbi.nlm.nih.gov/26849671/ https://doi.org/10.1007/s00299-015-1925-3

[43] Li, Q., Wang, G., Wang, Y., Yang, D., Guan, C. and Jing, J. (2019) Foliar Application of Salicylic Acid Alleviated the Cadmium Toxicity by Modulation the Reactive Oxygen Species in Potato. Excotoxicology Environmental Safety, 172, 317-325. https://www.pubmed.ncbi.nlm.nih.gov/30721875/ https://doi.org/10.1016/j.ecoenv.2019.01.078

[44] Guo, B., Liu, C., Liang, Y., Li, N. and Fu, Q. (2019) Salicylic Acid Signals Plant Defense Cadmium Toxicity. International Journal of Molecular Sciences, 20, 2960. https://www.cbi.nlm.nih.jov/pmc/articles/PMC6627907/ https://doi.org/10.3390/ijms20122960

[45] Sharma, A., Sidhu, G.P.S., Araniti, F., Bresti, M., Shahzad, B., Tripathi, D.K., Brestic, M., Skalicky, M. and Land, M. (2020) The Role of Salicylic Acid in Plants Exposed to Heavy Metals. Molecules, 25, 540.

https://www.nvbi.nlm.nih.gov/pmc/articles/PMC7037467/

https://doi.org/10.3390/molecules 25030540 


\section{Abbreviations}

Sewage sludge level (SSL),

Indole acetic acid (IAA),

Salicylic acid (SA). 